\title{
Efficacy of Lemna minor and Typa latifolia for the treatment of textile industry wastewater in a constructed wetland under citric acid amendment:
} A lab scale study

\author{
MUJAHID FARID ${ }^{1}$, HAFIZ KHUZAMA ISHAQ ${ }^{2}$, \\ SHAFAQAT ALI ${ }^{3}$ AND SHEHARYAAR FARID ${ }^{4}$ \\ ${ }^{1}$ University of Gujrat \\ ${ }^{2}$ University of Gujrat, Hafiz Hayat Campus, Gujrat, 50700, \\ ${ }^{3}$ China Medical University \\ ${ }^{4}$ University of Porto \\ Presenting Author: mujahid726@yahoo.com
} Pakistan

Heavy metals (HMs) contamination is currently a major environmental concern; as most agricultural land is being polluted from municipal discharge. Among various other pollutants, lead $(\mathrm{Pb})$, copper $(\mathrm{Cu})$ and chromium $(\mathrm{Cr})$ are one of the most harmful heavy metals, enters into the food chain through the irrigation of crops with an industrial effluent. The present study was performed to evaluate the toxic effects of textile effluents and performance of citric acid (CA) on phytoextraction potential of Lemna minor L. and Typha latifolia $L$. in an artificial designed wetland. Different doses of textile wastewater $(0,25,50,75$, and $100 \%)$ and CA $(10 \mathrm{mM})$ were applied alone and in combinations to plants. Plants were harvested and the data was recorded regarding agronomic traits, photosynthetic pigments, antioxidant enzymes, reactive oxygen species (ROS), electrolytic leakage (EL) and heavy metals uptake and accumulation. Our results depicted that the concentration and accumulation of $\mathrm{Pb}, \mathrm{Cu}$ and $\mathrm{Cr}$ in different parts of T. Latifolia plant was increased with and without CA addition. The $\mathrm{Pb}, \mathrm{Cu}$ and $\mathrm{Cr}$ concentration increased in leaf by $(279,240 \& 171 \%)$, stem by $(192,172 \& 154 \%)$ and root by (224, $183 \& 168 \%)$ respectively. Similarly, the accumulation of $\mathrm{Pb}, \mathrm{Cu}$ and $\mathrm{Cr}$ increased in leaf by $(91,71 \& 36 \%)$, stem by ( 57 , $46 \& 36 \%)$ and root by $(76,53 \& 45 \%)$ respectively in plants treated with $100 \%$ textile effluent as compared to the $25 \%$ textile effluent treated plants. In L. minor, the concentration of $\mathrm{Pb}, \mathrm{Cu} \&$ $\mathrm{Cr}$ increased 542, 411 and $397 \%$ while accumulation increase $101,59 \& 55 \%$ respectively.. 